\title{
Limitações à \\ discricionariedade \\ da administração \\ na nomeação de \\ comissionados e \\ aprovados em concurso
}

\author{
Marcos Sepúlveda \\ BiAnCA PfeFfer ${ }^{2-3}$
}

\section{RESUMO}

O objetivo desse artigo é analisar o ato de nomeação entre servidores comissionados e aprovados em concursos públicos nos casos em que há desproporcionalidade no quadro de pessoal, ou seja, quando os comissionados formam mais de $50 \%$ por cento da estrutura administrativa. Nesse sentido, a pesquisa baseou-se na recente tese de repercussão geral (1010) do STF que determina que deve haver proporcionalidade na criação de cargos comissionados em relação aos efetivos. O estudo é divido em três partes: as origens da Tese 1010 o ato de nomeação de servidores e o cabimento de reclamação constitucional.

1 Mestre em Ciência Política pela Universidade Federal Fluminense (UFF), Niterói (RJ), Brasil. Correo-e: marcosaraujoba@gmail.com - Enlace ORCID: https://orcid.org/0000-0002-32606635.

2 Especialista em Direito Processual Civil pela uninTer Educacional SA: Curitiba (PR), Brasil Correo-e: bianca.pfeffer@hotmail.com. Enlace ORCID: https://orcid.org/0000-0003-06476301. Fecha de recepción: 20 de enero de 2020. Fecha de modificación: 3 de febrero de 2020. Fecha de aceptación: 2 de mayo de 2020. Para citar el artículo: Sepúlveda, Marcos, Pfeffer, BIANCA, "Limitações à discricionariedade da administração na nomeação de comissionados e aprovados em concurso", Revista digital de Derecho Administrativo, Universidad Externado de Colombia, n. ${ }^{\circ} 24,2020$, pp. 241-268. DOI: https://doi.org/10.18601/21452946.n24.10.

3 Agradecemos a Luiz Henrique Cauper pelas inúmeras discussões sobre o tema. 
Palavras-chave: proporcionalidade; razoabilidade $_{i}$ discricionariedade concurso público; servidor público.

\section{Limitaciones a la discrecionalidad de la Administración en el nombramiento de comisionados y aprobados en concurso público}

\section{RESUMEN}

El objetivo de ese artículo es analizar el acto de nombramiento de servidores comisionados y aprobados en concursos públicos, cuando hay desproporcionalidad en el cuadro de personal, o cuando los comisionados forman más del $50 \%$ de la estructura administrativa. En ese sentido, la investigación se basó en la reciente Tesis 1010 de la Corte Suprema de Brasil, la cual determina que debe haber proporcionalidad en la creación de cargos comisionados en relación con los efectivos. El estudio se divide en tres partes: los orígenes de la Tesis 1010, el acto de nombrar servidores y la queja constitucional.

Palabras clave: proporcionalidad, razonabilidad, discrecionalidad, concurso de oposición, empleado estatal.

\section{Limits to the Administration's Discretion in the Appointment of Temporary Civil Servants and Those Accepted Through Merit-Based Examinations}

\section{ABSTRACT}

This paper examines the appointment of temporary civil servants and those individuals accepted through merit-based examinations, when there is a lack of proportion in the Administration's workforce, that is to say, when temporary employees made more than $50 \%$ of its personnel. In this respect, the research is built on the recent legal reasoning 1010 of the Brazilian Supreme Court, which sets a limit to the creation of temporary employment within the Public Administration. Temporary public employment should then be proportional to effective public positions in administrative agencies. The study is divided into three parts: the origins of the 1010 Thesis, the appointment of public servants and the constitutional complaint.

Keywords: Proportionality; Reasonableness; Administrative Discretion; Merit-based Exam, Public Employee. 


\section{INTRODUÇÃO}

Esse artigo tem como objeto de estudo os limites do poder discricionário na nomeação entre servidores comissionados e candidatos aprovados em concurso público. Neste ponto, foca-se nas questões constitucionais e administrativas que podem limitar a nomeação de comissionados por parte da Administração Pública, quando haja concurso público homologado com aprovados dentro do número de vagas do edital aguardando o ato de nomeação. Questiona-se: quais são os limites do poder discricionário no ato de nomeação entre servidores comissionados e candidatos aprovados em concurso público?

Nesse sentido, a investigação visa analisar se, quando verificado um número excessivo de comissionados, o ato discricionário se transmuta em vinculado em relação à nomeação dos aprovados dentro do número de vagas, e caso positivo, quais seriam os fundamentos para sua defesa.

Entrementes, é importante destacar a recente decisão no RE 1.041.210/SP com repercussão geral (Tese 1010), na qual a Suprema Corte decidiu que o quadro de pessoal da Administração Pública deve guardar proporcionalidade entre comissionados e efetivos, não sendo possível que servidores precários sejam mais de $50 \%$ por cento do quadro de pessoal.

Desse modo, propõe-se avaliar o impacto da Tese 1010 para a Administração Pública, mas focando como isso pode limitar o ato de nomeação por parte do gestor público quando haja um concurso público homologado e com aprovados dentro do número de vagas aguardando a nomeação.

Num primeiro momento, serão analisadas as decisões do Supremo Tribunal Federal que culminaram na Tese 1010 de Repercussão Geral sobre o tema. Além disso, será tratado como a jurisprudência progrediu ao longo dos anos sobre o tema. Posteriormente, será explicado como essa Tese pode impactar na nomeação de servidores comissionados, quando há aprovados em concurso aguardando a nomeação. Percorre-se também os temas de patrimonialismo e estrutura da burocracia brasileira.

Ademais, será trabalhada a força vinculante dos precedentes dos Tribunais Superiores e o dever de observância pela Administração Pública, conforme as normas do Código de Processo Civil e as alterações da Constituição Federal pela Emenda Constitucional n. ${ }^{\circ}$ 45/2004. Ainda, tratar-se-á da possibilidade do uso da reclamação constitucional com o intuito de exigir do administrador a efetividade da decisão da Corte, permeando tal ponto com o sistema jurídico da common law.

\section{A TESE 1010 DO STF E SUAS ORIGENS}

O STF enfrentou, ainda nos primeiros anos do século XXI, a questão da discricionariedade da Administração Pública na criação de cargos comissionados. Reluz do Recurso Extraordinário 365368/SC, o debate sobre a criação de 
cargos comissionados em quantitativo superior aos previstos de cargo de servidor efetivo.

Neste julgado, restou assentado que é passível de análise pelo Judiciário a edição de normas legais que possam confrontar o artigo 37, II da Constituição Federal, por meio do princípio da razoabilidade, proporcionalidade, moralidade, impessoalidade correlacionando os meios e fins dos atos normativos ${ }^{4}$.

A respeito dos princípios da proporcionalidade e da razoabilidade, de incidência recorrente nas decisões do Supremo, apesar da Corte, por vezes, não os distinguir (ADI 2667 MC/DF ${ }^{5}$ RE 200.844-3 AgR ${ }^{6}$ ), a doutrina preconiza que o primeiro tem origens no direito alemão, ao passo que a razoabilidade deriva do direito anglo-saxão ${ }^{7}$.

Há na proporcionalidade uma relação causal entre o meio a ser utilizado e o fim pretendido pela norma ${ }^{8}$, exigindo-se do Poder Público medidas adequadas (meio e objeto legítimos para atingir o fim pretendido), necessárias (uso de meios menos invasivos, restringindo somente os direitos indispensáveis para o caso concreto) e proporcionais em sentido estrito (por meio do sopesamento, de maneira que "quanto maior for o grau de não satisfação ou de afetação de um princípio, tanto maior terá que ser a importância da satisfação do outro" ${ }^{\prime \prime}$.

A razoabilidade refere-se à análise das condições individuais dos sujeitos envolvidos, considerando-as nas decisões. Trata-se da vedação a medidas absurdas, podendo ser caracterizada por três sentidos segundo Ávila ${ }^{10}$, sendo eles o dever de equidade, congruência e equivalência.

Verifica-se no trecho extraído da Ementa da Medida Liminar da Ação Direta de Inconstitucionalidade $n$. $^{\circ} 2667$ o uso confuso dos princípios, em que o Supremo cita a razoabilidade com o conceito de proporcionalidade:

As normas legais devem observar, no processo de sua formulação, critérios de razoabilidade que guardem estrita consonância com os padrões fundados no princípio da proporcionalidade, pois todos os atos emanados do Poder Público

4 STF, Recurso Extraordinário: 365368/SC. DJ: 22/05/2007. Disponível em: http://portal. stf.jus.br/processos/detalhe.asp?incidente $=2076706$, acesso em $20 \mathrm{de}$ dez. de 2019 .

5 STF, Ação Direta de Inconstitucionalidade: 2667/DF (Medida Liminar). DJ: 12/03/2004 Disponível em: http://www.stf.jus.br/portal/peticaolnicial/verPeticaolnicial.asp?base= ADIN\&s1 $=2667$ \& processo $=2667$, acesso em 27 de nov. de 2019.

6 STF, Agravo Regimental no Recurso Extraordinário: 200.844-3/PR. DJ: 25/06/2002. Disponível em: http://redir.stf.jus.br/paginadorpub/paginador.jsp?docTP=AC\&docID =330565, acesso em 27 de dez. de 2019.

7 Luís Roberto Barroso, Direito Constitucional Contemporâneo, São Paulo: Saraiva Educação, 2020, passim.

8 Marcelo Novelino, Curso de Direito Constitucional, Salvador: JusPodivm, 2017, p. 307.

9 Robert AleXY, Teoria dos Direitos Fundamentais. São Paulo: Malheiros, 2008, p. 162.

10 Humberto Ávila, Teoria dos Princípios: da definição à aplicação dos princípios jurídicos, São Paulo: Malheiros, 2004, p. 103. 
devem ajustar-se à cláusula que consagra, em sua dimensão material, o princípio do "substantive due process of law"11.

Mais adiante, em outro notável julgado, ADI 4125, o Supremo fulminou mais de 35 mil cargos comissionados criados pelo Poder Executivo do Estado de Tocantins. Em iguais termos, essa decisão se consolidou no sentido de que a criação de inúmeros cargos comissionados não encontra respaldo na moralidade administrativa, incorrendo na violação aos princípios da proporcionalidade e da razoabilidade, além de outros implícitos e explícitos na Constituição Federal ${ }^{12}$.

Insta salientar que, apesar de funções de confiança e cargos em comissão serem ambos destinados estritamente às atribuições de chefia, direção e assessoramento, diferem-se pelo fato de que as funções de confiança serem exercidas de modo exclusivo por servidores estatutários, com cargos efetivos, ao passo que os comissionados são ocupados por qualquer pessoa, servidores públicos ou não ${ }^{13}$.

Nesse elastério, a Tese 1010 prevê observância estrita aos cargos em comissão - destinados exclusivamente para funções de direção, chefia e assessoramento. Dessa forma, descarta-se a possibilidade que servidores precários desempenhem atividades rotineiras da Administração, em especial para incumbências técnicas, operacionais e burocráticas. Além disso, deve haver relação de confiança entre a Administração e os servidores comissionados, assim como proporcionalidade - não podendo superar o número de servidores efetivos - e, por fim, as atribuições devem ser feitas de forma clara e objetiva ${ }^{14}$.

a) A criação de cargos em comissão somente se justifica para o exercício de funções de direção, chefia e assessoramento, não se prestando ao desempenho de atividades burocráticas, técnicas ou operacionais; b) tal criação deve pressupor a necessária relação de confiança entre a autoridade nomeante e o servidor nomeado; c) o número de cargos comissionados criados deve guardar proporcionalidade com a necessidade que eles visam suprir e com o número de servidores ocupantes de cargos efetivos no ente federativo que os criar ${ }_{i}$ e d) as atribuições dos cargos em comissão devem estar descritas, de forma clara e objetiva, na própria lei que os instituir ${ }^{15}$.

11 STF, op. cit., loc. cit.

12 STF, Ação Direta de Inconstitucionalidade: 4125/TO. DJ: 15/02/2011. Disponível em: http://portal.stf.jus.br/processos/detalhe.asp?incidente=2635406, acesso em $20 \mathrm{de}$ dez. de 2019 .

13 Rafael Carvalho Rezende Oliveira, Curso de Direito Administrativo, Rio de Janeiro: Forense São Paulo: Método, 2018, p. 702.

14 STF, Recurso Extraordinário: 1.041.210/SP. DJ: 22/05/2019. Disponível em: http://portal stf.jus.br/processos/detalhe.asp?incidente $=5171382$, acesso em 20 de dez. de 2019 .

15 Ibid., loc. cit. 
Logo, reforçando o que poderia ser o esvaziamento da norma constitucional sobre a obrigatoriedade de concurso público e a assimetria entre servidores efetivos e comissionados, e tal prática deve ser combatida, visto que esse círculo vicioso contradiz a Constituição Federal. A intervenção judicial mostra-se imperiosa para sanar tais ilegalidades e burlas aos princípios constitucionais.

No entanto, há uma intensa controvérsia no que toca à intervenção judicial na aplicação da Constituição Federal, tendo surgido na Suprema Corte Americana, por esta razão, um embate entre as correntes interpretativistas e não interpretativistas, que no Poder Judiciário brasileiro são mais comumente conhecidas como procedimentalistas e substancialistas, respectivamente.

Para os interpretativistas, a interpretação da Constituição deve se dar de modo conservador, pautado na vontade do constituinte originário e pela literalidade do texto, atendo-se à legitimidade democrática do Poder Legislativo. Entendem que o papel dos juízes deve se ater à leitura da lei, e não à teoria política ou moral do intérprete ${ }^{16}$. Os não interpretativistas possuem um viés mais progressista, defendendo que a Constituição deve ser atualizada e desenvolvida com base na exigência das presentes gerações, conferindo ao Judiciário, portanto, um papel central nas mudanças sociais e na incorporação de novos direitos.

As correntes procedimentalistas e substancialistas também debatem sobre o dirigismo que uma Constituição deve adotar para a efetivação de direitos. Para os primeiros, a Carta Magna deve regular o processo deliberativo, ou seja, deve preservar os canais da democracia, deixando com que a sociedade escolha o modo de implementação de direitos. Assim, as decisões não devem ocorrer por meio do Judiciário (rejeitando, portanto, o ativismo), mas sim por meio do Legislativo. O papel do Judiciário resume-se a garantir as regras do debate democrático, permitindo com que a concretização do direito esteja sempre aberta ao processo deliberativo ${ }^{17}$.

Os substancialistas defendem uma Constituição Dirigente (termo cunhado pelo constitucionalista português José Joaquim Gomes Canotilho $\left.{ }^{18}\right)$, de maneira que cabe ao Poder Judiciário a implementação direta de direitos de forma generalizada, com ampla judicialização, inclusive política, dos projetos constitucionais ${ }^{19}$.

16 Marcelo Novelino, op. cit., p. 152.

17 Maria Aparecida Alkimin e Lincoln Zub Dutra, "O ativismo judicial como instrumento de transformação do Estado Democrático de Direito", Revista Direito \& Paz, v. 1, n. ${ }^{\circ} 34$ 2016, pp. 300-318.

18 José Joaquim Gomes CANOTILHO, Constituição dirigente e vinculação do legislador: contributo para a compreensão das normas constitucionais programáticas, Coimbra: Editora Coimbra, 2001, passim.

19 Luís Roberto Barroso, O controle de constitucionalidade no direito brasileiro, São Paulo: Saraiva Educação, 2019, passim. 
Para Müller ${ }^{20}$, o direito constitucional deve ter como fulcro a caracterização e manutenção da legitimidade por parte da sociedade, além da efetividade das normas constitucionais, tendo como finalidade a concretização da Constituição e das normas infraconstitucionais.

o direito constitucional, a legislação constitucional e a concretização da constituição têm a incumbência de atualizar a unidade política da associação da sociedade no Estado [staatlicher Verband], de fornecer fundamentos e critérios de aferição à instituição e efetividade das normas no ordenamento jurídico infraconstitucional e de assegurar, paralelamente a essa garantia de legalidade, também a geração, o reconhecimento e a preservação da legitimidade no sentido do que é aceita como conteúdo "correto" pela sociedade ${ }^{21}$ (itálicos no original).

No caso da decisão analisada, depreende-se a adoção, pelo STF, de uma clara corrente substancialista, discutindo dentro do Poder Judiciário o modo de aplicação do art. 37, II da Constituição Federal em cotejo com os demais princípios explícitos e implícitos, entre os quais a proporcionalidade, a razoabilidade, a isonomia, a moralidade, e, com isso, exigindo que a criação dos cargos pelo Poder Legislativo siga os parâmetros assentados na Tese. Essa mesma corrente permite que o Poder Judiciário decida, com base nas teses firmadas, sobre a constitucionalidade de uma lei que tenha criado cargos comissionados.

Destaca-se que o Supremo Tribunal Federal possui o papel de resguardar a aplicabilidade da Constituição Federal e, apesar da controvérsia sobre seu enquadramento como Corte Constitucional, prevalece o entendimento doutrinário no sentido de não se tratar de uma Corte Constitucional propriamente dita ${ }^{22}$.

Isso porque uma Corte Constitucional é criada para tratar em caráter especial e de forma exclusiva do contencioso constitucional. No Brasil, o Supremo Tribunal Federal acumula a análise dos métodos difuso e concentrado de controle de constitucionalidade, além de atuar como Corte de Apelação, em razão do alargamento das competências atribuídas pela Magna Carta (art. 102). Outrossim, a diferença do modelo de Corte proposto por Hans Kelsen ocorre pelo fato do mandato ser vitalício, ao passo que na maioria das Cortes Constitucionais a nomeação ocorre pelo Parlamento e é temporária ${ }^{23}$.

20 Friedrich Müller, Métodos de Trabalbo do Direito Constitucional, São Paulo: Max Limonad, 2000, p. 68.

21 Ibid., loc. cit.

22 Gilmar Ferreira Mendes e Paulo Gustavo Gonet Branco, Curso de Direito Constitucional, São Paulo: Saraiva, 2012, p. 1320. No mesmo sentido: Dirley da Cunha Junior, Curso de Direito Constitucional, Salvador: Juspodivm, 2012, pp. 1129-1130.

23 AlvaCir Alfredo Nicz, "A Jurisdição Constitucional e seu alcance: Cortes Constitucionais e Supremo Tribunal Federal", in: Jorge Miranda (coord.), Justiça Constitucional. São Paulo: Almedina Brasil, 2018, passim. 
Entende a doutrina de Garcia e Pacheco ${ }^{24}$, que ao ser verificado que o número de comissionados supera o número de efetivos, não há outra decisão a ser tomada, senão a inconstitucionalidade das normas que instituíram tais cargos sem observância ao princípio da proporcionalidade e da moralidade, precipuamente em razão das possíveis motivações que ensejaram a nomeação, como o apadrinhamento político, a troca de favores entre agentes, entre outros.

Compreende-se, portanto, que a edição de Lei ou de qualquer outro ato normativo que minore o princípio constitucional do concurso público pode ser afastada pelo Poder Judiciário, não cabendo ser invocado o Poder Legiferante neste aspecto, inclusive como bem ressalta Frischeisen ${ }^{25}$ :

as dúvidas sobre essa margem de discricionariedade devem ser dirimidas pelo Judiciário, cabendo ao Juiz dar sentido concreto à norma e controlar a legitimidade do ato administrativo (omissivo ou comissivo), verificando se o mesmo não contraria sua finalidade constitucional, no caso, a concretização da ordem social constitucional.

É evidente que a criação de inúmeros cargos comissionados, sem observância ao quantitativo mínimo de servidores efetivos, minora os fins do art. 37, II da Carta Magna: a regra constitucional do concurso público. Ressalta-se, consoante à Tese 1010 e ao art. 37, que cargos em comissão pressupõem relação de confiança, não podendo ser destinado às atividades rotineiras, administrativas e burocráticas do ente que os instituir. Diante disso, passível de invocar também o subprincípio da necessidade.

De acordo com Neto e Sarmento ${ }^{26}$, este princípio impede que tais atos do poder público restrinjam em demasia algum direito ou interesse que seja garantido à sociedade. Como foi exposto, caso se admitisse que a administração pudesse criar excessivamente tais cargos, impediria a igualdade de acesso aos cargos públicos, por exemplo. Até porque a boa doutrina já lecionava outrora que a validade dos atos, in casu, o ato de nomear servidores comissionados, está contida na função final:

Para distinguir o efeito através do qual se cumpre a função específica do ato (ou fato) de outros e diversos efeitos jurídicos que o mesmo pode produzir, chama-se ao primeiro, efeito final, típico, principal ou definitivo. E é em relação ao adimplemento ou inadimplemento da sua função específica, isto é, à realização do

24 Emerson Garcia e Rogério Pacheco, Improbidade Administrativa, Rio de Janeiro: Lúmen Júris, 2013, p. 505.

25 Luiza Cristina Fonseca Frischeisen, Políticas Públicas - A Responsabilidade do Administrador eo Ministério Público, São Paulo: Max Limonad, 2000, p. 97.

26 Cláudio Pereira de Souza Neto e Daniel Sarmento, Direito Constitucional - Teoria, bistória e métodos de trabalho, Belo Horizonte: Fórum, 2016, p. 476. 
efeito final, que praticamente se põe a questão da eficácia ou da ineficácia do ato administrativo, como do fato jurídico em geral ${ }^{27}$.

Depreende-se das decisões do Supremo, que o princípio da proporcionalidade se opera tanto na proteção contra excessos estatais, quanto na proibição de proteção deficiente ${ }^{28}$. A Constituição permite margens de ação para que os aplicadores da Lei decidam quais são as formas de proteção dos direitos fundamentais. Ocorre que essa decisão deve ser pautada pela proporcionalidade, tanto por meio da proibição ao excesso, quanto pela proibição da proteção deficiente, sendo que o primeiro caso se refere à proibição de intervenção e, no segundo, como imperativo de tutela ${ }^{29}$.

Isso porque o princípio da proporcionalidade não ocorre apenas para impedir os abusos cometidos pelo Estado (proteção contra o excesso estatal), mas também para exigir uma prestação de caráter positivo, podendo, neste aspecto, servir como critério determinante para a estruturação dos direitos fundamentais. Esse duplo viés garante a vinculação dos atos estatais ao conteúdo material da Constituição, reduzindo a discricionariedade do Legislativo ${ }^{30}$.

Assim, há uma nítida proibição da proteção deficiente da norma constitucional que visa assegurar a isonomia e a igualdade de acesso ao serviço público (Constituição Federal, arts. 5. ${ }^{\circ}$, caput, e 37, caput e inciso II) (Untermaßverbot), que reverbera no princípio da proporcionalidade e, nesse sentido, o impedimento de criação de cargos comissionados que não observem tal cláusula, mutatis mutandis ao exposto por Streck ${ }^{31}$.

Sopesando os subprincípios da proporcionalidade e a vedação à proteção deficiente do Estado com relação aos princípios traçados pela norma constitucional, por consequência, o Supremo entendeu que há garantia de que os cargos públicos devem ser preenchidos por não menos de $50 \%$ através da regra do concurso público.

Nota-se, após a distinção dos princípios, a eminente importância da análise das medidas tomadas pelo Poder Público com base nos subprincípios da proporcionalidade, verificando por etapa o preenchimento da adequação (relação entre meio e fim), necessidade (a busca por meio alternativo menos

27 Flávio Bauer Novel, "A eficácia dos atos administrativos", Revista de Direito Administrativo, v. 60,1960, p. 21

28 STF, Questão de Ordem na Repercussão Geral no Recurso Extraordinário: 966.177/RS DJ: 07/06/2017. Disponível: http://redir.stf.jus.br/paginadorpub/paginador.jsp?docTP= TP\&docID=749049106, acesso em 01 de dez. de 2019.

29 Gilmar Ferreira Mendes e Paulo Gustavo Gonet Branco, op. cit., p. 685.

30 Lenio Luiz StReCK, "Bem jurídico e Constituição: da proibição de excesso (Übermaßverbot) à proibição de proteção deficiente (Untermaßverbot) ou de como não há blindagem contra normas penais inconstitucionais", Boletim da Faculdade de Direito: Universidade de Coimbra, v. 80, 2004, p. 332.

31 Ibid., pp. 332-333. 
lesivo) e proporcionalidade em sentido estrito (quando a perda é maior do que o ganho), como bem expõe Pedra ${ }^{32}$.

Da mesma forma, é o conceito de "sobreinterpretação" da Constituição. Para Guastinii ${ }^{33}$, a Constituição não possui espaços em "brancos", que possam ser vistos como lacunas normativas. Disso decorre, inclusive, o princípio da proporcionalidade que, embora não esteja explícito na Constituição Federal, é utilizado para verificar a finalidade dos atos normativos do poder público. Nesse diapasão, violar um princípio constitucional significa violar todo o sistema da Constituição Federal ${ }^{34}$. Assim, a perda de eficácia dos comandos constitucionais em virtude da arbitrariedade do administrador público merece de pronto ser repelida.

violar um princípio é muito mais grave que transgredir uma norma qualquer. A desatenção ao princípio implica ofensa não apenas a um específico mandamento obrigatório, mas a todo sistema de comandos. É a mais grave forma de ilegalidade ou inconstitucionalidade, conforme o escalão do princípio atingido, porque representa insurgência contra todo o sistema, subversão de seus valores fundamentais, contumélia irremissível a seu arcabouço lógico e corrosão de sua estrutura mestra. Isto porque, com ofendê-lo, abatem-se as vigas que o sustêm e alui-se toda estrutura nelas esforçada ${ }^{35}$.

A forma de pensar a Constituição não mais como mera limitação do poder político surgiu após as transformações sociais ocorridas após a Segunda Guerra Mundial. Busca-se a efetiva concretização dos princípios fundamentais, como a isonomia, a igualdade, a moralidade, e a efetividade, sendo que a decisão do Supremo acerca da limitação da nomeação de servidores comissionados advém desse fenômeno chamado neoconstitucionalismo, ante a primazia da força normativa constitucional ${ }^{36}$. No magistério de Barroso ${ }^{37}$, é possível observar o neoconstitucionalismo como várias transformações no Estado e no Direito Constitucional, tendo como marco:

32 Anderson Sant'Ana Pedra, "A constitucionalização do direito e o controle do mérito do ato administrativo pelo judiciário", in: Walber de Moura Agra, Celso Luiz Braga de Castro e André Ramos Tavares (orgs.), Constitucionalismo: os desafios do terceiro milênio, Belo Horizonte: Fórum, 2008, p. 67.

33 Riccardo GuASTINI, "A Constitucionalização do ordenamento jurídico e a experiência italiana", in: Claudio Pereira de Souza Neto e Daniel Sarmento (coords.), A Constitucionalização do Direito: fundamentos teóricos e aplicações específicas, Rio de Janeiro: Lumen Juris, 2007, p. 276.

34 Celso Antônio Bandeira de Mello, Curso de Direito Administrativo, São Paulo: Malheiros, 2008, p. 943.

35 Ibid., loc. cit.

36 Álvaro de Azevedo Gonzaga e Roberto Bejato Junior, "Hermenêutica Jurídica", in: Álvaro de Azevedo Gonzaga e Nathaly Campitelli Roque (coords.), Vade mecum bumanístico, Rio de Janeiro: Forense -São Paulo: Método, 2014, p. 314. 
filosófico, o pós-positivismo [...] (ii) como marco bistórico, a formação do Estado constitucional de direito, após a $2^{\text {a }}$ Guerra Mundial, e, no caso brasileiro, a redemocratização da institucionalidade pela Constituição de 1988 ; e (iii) como marco teórico, o conjunto de novas percepções e de novas práticas, que incluem a força normativa da Constituição (inclusive e, sobretudo, aos princípios constitucionais), a expansão da jurisdição constitucional e o desenvolvimento de uma nova dogmática da interpretação constitucional, envolvendo novas categorias, como princípios, as colisões de direitos fundamentais, a ponderação e a argumentação (itálico no original).

Feitas as considerações iniciais sobre a Tese 1010 que incidem diretamente no tema sobre o ato de nomeação de servidores comissionados, quando há aprovados em concursos dentro do número de vagas aguardando a nomeação, passe-se para a segunda parte deste trabalho.

\section{DISCRICIONARIEDADE: A NOMEAÇÃO DE COMISSIONADOS E APROVADOS}

No ano de 2011, após o STF apreciar a ADI $4125^{[38]}$ do Estado do Tocantins, que criou de maneira desrazoável milhares de cargos comissionados, o Supremo passou a reconhecer o direito subjetivo aos aprovados em concurso público: "o candidato aprovado em concurso público dentro do número de vagas previsto no edital possui direito subjetivo à nomeação ${ }^{\prime 39}$. No mesmo sentido, o recurso extraordinário 837311/PI - também de Repercussão Geral ${ }^{40}$.

Embora haja discricionariedade no ato de nomeação de aprovados em concurso quanto à conveniência e oportunidade do momento desse ato, conforme exposto no Recurso Extraordinário 598099/MS ${ }^{41}$, esse entendimento deve ser interpretado consoante ao delineado na Constituição Federal, em especial ao art. 37, II, e da decisão citada: devem ser considerados princípios de publicidade, impessoalidade, isonomia no ato de nomeação, a fim que seja efetivado o princípio do concurso público.

Apesar de inexistir consenso na doutrina acerca dos elementos do ato administrativo, prevalece o seguinte rol: agente competente, forma, finalidade, motivo e objeto, todos mencionados no art. 2. ${ }^{\circ}$ da Lei n. ${ }^{\circ}$ 4.717/1965. Dentre estes elementos, a discricionariedade do administrador público aplica-se para o motivo de fato, podendo optar entre os diversos motivos elencados pela Lei para justificar a edição de um ato administrativo; e para o objeto, nos casos

38 STF, op. cit., loc. cit.

39 STF, Recurso Extraordinário: 598.099/MS. DJ: 03/10/2011. Disponível em: http://portal. stf.jus.br/processos/detalhe. asp?incidente $=2667158$, acesso em 20 de dez. de 2019 .

40 STF, Recurso Extraordinário: 837.311/PI. DJ: 09/12/2015. Disponível em: http://portal.stf. jus.br/processos/detalhe. asp?incidente $=4634356$, acesso em 20 de dez. de 2019.

41 STF, op. cit., loc. cit. 
em que a Lei delimita o conteúdo, mas não o define de modo exaustivo, conferindo margem de apreciação ao administrador ${ }^{42}$.

Em regra, consoante o entendimento doutrinário e jurisprudencial, o controle judicial dos atos oriundos dos demais poderes deve restringir-se à análise da legalidade, não podendo o Poder Judiciário substituir o administrador ou o legislador para definir critérios de oportunidade e conveniência, sob pena de afronta ao princípio da separação dos poderes previsto no artigo $2 .^{\circ} \mathrm{da}$ Constituição Federal ${ }^{43}$.

A bem da verdade, a mera nomeação de servidores comissionados per si não gera preterição aos aprovados dentro do número de vagas. No entanto, uma vez constatado que o número de servidores comissionados é desproporcional ao número de efetivos, os aprovados dentro do número de vagas possuem direito à nomeação imediata por força constitucional do art. 37, II, em consonância com a Tese 1010 de Repercussão Geral, transmutando-se o ato discricionário em vinculado.

Ademais, consoante o entendimento jurisprudencial dos Tribunais Superiores ${ }^{44}$, preconizada nos enunciados de súmulas do Supremo Tribunal Federal n. ${ }^{\circ} 473$ e 346, a Administração Pública pode anular, a qualquer tempo, o ato de provimento flagrantemente inconstitucional, pois o decurso do tempo não importa em convalidação de atos que afrontem a regra do concurso público, por inexistir prazo prescricional para a anulação de ato que afronte diretamente a Constituição ${ }^{45}$, não se aplicando, desse modo, o disposto no artigo 54 da Lei n. ${ }^{\circ}$ 9.784/1999.

Parafraseando, o Min. Ricardo Lewandowski no HC 152.856/DF46 que "nossa Constituição não é uma mera folha de papel, que pode ser rasgada sempre que contrarie as forças políticas do momento", é imperioso afirmar que se a Constituição prevê como regra o ingresso em cargos públicos mediante concurso público, deve-se rejeitar o conceito de Constituição de Ferdinand Lassale ${ }^{47}$.

Para este autor, a Constituição jurídica (ou escrita) difere da real (ou efetiva). Aponta como verdadeiro fundamento da Carta de um país os fatores reais e efetivos de poder vigente, formado por forças políticas atuantes na conservação das instituições, como os banqueiros, a monarquia, a grande burguesia, entre outras. Assim, ante a prevalência da vontade dos titulares de poder, a 
Constituição jurídica deve corresponder aos fatores de poder que regem o país, pois, caso contrário, não passará de uma mera "folha de papel"48.

Consoante explanado pelas palavras do Ministro Ricardo Lewandowski (Habeas Corpus: 152.856/DF ${ }^{49}$ ), tal conceito de Carta Política de um país deve ser rejeitado, adotando-se o critério normativo classificado ontologicamente por Loewenstein ${ }^{50}$, segundo o qual a Constituição é aquela cujas normas dominam de fato o processo político, "Para ser real y efectiva, la constitución tendrá que ser observada lealmente por todos los interesados y tendrá que estar integrada en la sociedad estatal, y ésta en ella". Afasta-se, portanto, o caráter nominalista, que permite ampla discricionariedade do administrador para dispor sobre cargos comissionados e efetivos, dado que para a ordem constitucional nominalista, o processo político não se adapta às normas, que carece de força normativa.

Nesse mesmo elastério, o tratadista espanhol Enterría ${ }^{51}$, ao afirmar que a forma normativa da Constituição estabelece limites ao poder discricionário da Administração Pública, assim como delimita garantias e direitos em prol do interesse público e toda sociedade.

Por una parte, configura y ordena los poderes del Estado por ella construidos; por otra, establece los límites del ejercicio del poder y el ámbito de libertades y derechos fundamentales, así como los objetivos positivos y las prestaciones que el poder debe de cumplir en beneficio de la comunidad.

Com base no princípio da força normativa da Constituição trabalhado por Hesse $^{52}$, dentre as demais hipóteses em que o Tribunal da Cidadania possui firme jurisprudência no sentido de garantir o direito subjetivo à nomeação e, portanto, tornando-a ato administrativo de caráter vinculado, destaca-se: (a) a aprovação dentro do número de vagas ${ }^{53}$; (b) a desistência de candidatos convocados dentro do prazo de validade do concurso, observada a ordem de classificação e a quantidade de vagas disponibilizadas ${ }^{54}$; (c) a abertura de novo concurso, enquanto vigente a validade do certame anterior, em relação aos candidatos cuja classificação seja alcançada pela divulgação de novas vagas ${ }^{55}$; (d) candidato aprovado fora do número de vagas nos casos de preterição na 
nomeação, observada a ordem classificatória ${ }^{56}, e$, ainda $;$ (e) quando houver contratações precárias e comprovação da existência de cargos vagos, a mera expectativa de direito à nomeação do candidato aprovado fora do número de vagas convola-se em direito subjetivo ${ }^{57}$.

Desta forma, verificado que a Administração Pública descumpriu tal regra e, portanto, havendo mais de $50 \%$ por cento do quadro pessoal formado por servidores comissionados, não há outra interpretação possível, senão a obrigação do administrador público em nomear in totum os aprovados dentro do número de vagas ou um percentual que atenue a desproporção.

É dizer que aqueles que estejam dentro do número de vagas obtenham a nomeação de forma imediata até que haja proporção entre efetivos e comissionados ou, até o devido preenchimento de todos os aprovados dentro do número de vagas, os quais detêm direito subjetivo à nomeação - a priori, nesse exposto, o que vier primeiro.

Interpretação outra infringiria a Tese 1010 e, por consequência, o art. 37, inciso II da Constituição Federal. Do mesmo modo, como o Supremo já decidiu que deve haver proporcionalidade na criação de cargos comissionados em relação aos efetivos, e que este deve ser ao menos de $50 \%$ do quadro total de pessoal, defender outro entendimento daria ao administrador discricionariedade quanto à aplicação da norma constitucional do princípio do concurso público, havendo violação ao princípio de isonomia, impessoalidade, moralidade, entre outros.

são normas que são sempre ou satisfeitas ou não satisfeitas. Se uma regra vale, então deve se fazer exatamente aquilo que ela exige; nem mais, nem menos. Regras contêm, portanto, determinações no âmbito daquilo que é fática e juridicamente possível $^{58}$.

Dessarte, o Poder Público ao possuir o instrumento imediato para correção da desproporcionalidade percentual, o concurso público homologado e em vigor, preserva o grau mínimo constitucional, a própria Constituição Federal, dando efetividade à Carta Magna e propiciando a participação cidadã na gestão pública.

Inclusive, o princípio da legalidade impõe interpretação em consonância aos demais princípios constitucionais, sejam estes explícitos ou implícitos. Nesse caso, poderia representar grave ofensa aos princípios da proporcionalidade e razoabilidade, caso fosse permitida a continuidade da desproporção havendo concurso público vigente. 30.054/SP. 
Entretanto, como se sabe, para o desempenho de uma Administração Pública impessoal, eficiente, inter alia, faz-se necessário que seus ocupantes sejam, ao menos em 50\%, ingressantes por meio do critério da meritocracia, ou seja, através de concurso público, a fim de garantir que a Administração Pública seja independente e autônoma. É sabido que servidores precários estão sujeitos à discricionariedade administrativa e à vontade política, o que impede o desenvolvimento adequado das funções públicas e, consequentemente, a prestação dos serviços de maneira eficiente e fidedigna à população.

Conforme a doutrina e jurisprudência ${ }^{59}$, a demissão dos servidores comissionados para os cargos de direção, chefia e assessoramento (artigo 37, inciso v da Carta Magna) ocorre ad nutum pela autoridade nomeante, sendo, portanto, desnecessária a motivação do ato e independentemente de instauração de procedimento administrativo disciplinar, sentença judicial transitada em julgado ou procedimento de avaliação periódica de desempenho, assegurado, em todos os casos, a ampla defesa (art. 5. ${ }^{\circ}$, inciso LV da Lei Maior), critérios estes exigidos apenas para os cargos providos por meio de concurso público (artigo 41, caput, e $\S 1 .^{\circ}$ da Constituição Federal).

A motivação do ato administrativo amplia e permite o controle externo do ato, precipuamente por meio da teoria dos motivos determinantes, visto que, em razão desta, "a validade do ato administrativo depende da correspondência entre os motivos nele expostos e a existência concreta dos fatos que ensejaram a sua edição"60. Desta maneira, sendo dispensável a motivação para a demissão dos comissionados, somente a sua eventual existência permite o controle pelo Poder Judiciário.

Outrossim, a exigência do provimento de cargos públicos por meio de concurso público vai ao encontro ao princípio da eficiência, incluído no caput do art. 37 da Carta Maior pela Emenda Constitucional 19/1998, que teve por objetivo a substituição da Administração Pública burocrática pela Administração Pública gerencial ${ }^{61}$, em conformidade com a razoável duração do processo judicial e administrativo previsto no art. 5. ${ }^{\circ}$, LXXVIII da Constituição Federal.

Ademais, a eficiência permite que a interpretação e a aplicação das normas se deem com base nas consequências jurídicas, consoante determinação prevista no artigo 20 da Lei de Introdução às Normas do Direito Brasileiro (Decreto-Lei 4.657/1942), acrescido pela Lei n. ${ }^{\circ} 13.655 / 2018$. Visa à finalidade, à efetividade e à economicidade, sem abandonar a forma determinada para $\mathrm{o}$

59 STJ, Recurso Ordinário em Mandado de Segurança: 14.220/TO. DJ: 04/02/2003.

60 Rafael Carvalho Rezende Oliveira, op. cit., p. 307.

61 Luiz Carlos Bresser Pereira, Reforma do Estado para a cidadania: a reforma gerencial brasileira na perspectiva internacional, Brasília: ENAP, 1998, passim. Ver também: LuIZ CARLOS BRESSER Pereira, "Gestão do setor público: estratégia e estrutura para um novo Estado", in: Luiz Carlos Bresser Pereira e Peter Spink (orgs.), Reforma do Estado e Administração Pública gerencial, Rio de Janeiro: Editora FGV, 2006, passim. 
ato, mas preocupando-se precipuamente com a efetividade, afinal como bem elenca Barroso ${ }^{62}$ : "toda norma constitucional é dotada de eficácia jurídica e deve ser interpretada e aplicada em busca de sua máxima efetividade".

No entanto, segundo Munhoz e Fidalgo ${ }^{63}$, somente será possível a aplicação deste princípio no ordenamento se observadas, dentre outras, as normas referentes ao estágio probatório previstas no artigo 41 da Constituição, os princípios licitatórios e do concurso público (artigo 37, incisos II e XXI do mesmo diploma), os instrumentos de delegação de serviços públicos à atividade privada regidos pelas Leis n. ${ }^{\circ}$ 8.987/1995 e 11.079/2004. Destaca-se, deste rol, a direta ligação com os princípios da isonomia, moralidade, igualdade.

Por consequência, a permanência de milhares de servidores comissionados ofende a moralidade, a eficiência, a impessoalidade, princípios expressos da Constituição Federal. Destarte, essas nomeações extravagantes de servidores precários debilitam a Administração Pública, pois mantém:

os ineptos e apaniguados, que costumam abarrotar as repartições públicas, num espetáculo degradante de protecionismo e falta de escrúpulos de políticos que se alçam e se mantêm no poder, leiloando empregos públicos ${ }^{64}$.

Esse paradigma advém do patrimonialismo brasileiro que oriunda da formação política e social brasileira. Destacando os ensinamentos de Faoro ${ }^{65}$, "o patrimonialismo, cuja legitimidade assenta no tradicionalismo - assim é porque sempre foi", satisfaz os donos do poder, que embora nominalmente seja o povo, na realidade são aqueles que gerem a estrutura do Estado. No mesmo sentido, $\operatorname{Costin}^{66}$ assevera a relação prejudicial à administração pública e à sociedade, quando detectados numerosos cargos em comissão.

Não diferente é o que entende Holanda ${ }^{67}$, no sentido de que a manutenção de milhares apadrinhados políticos favorece o interesse particular do gestor público, inclusive fomenta a corrupção. Desse modo, assevera-se que tal medida repercute na eficiência, visto que o ato de nomeação de comissionados é a relação de confiança, e não o desempenho do Estado, que pode ser auferido através de concurso público.

62 Luís Roberto Barroso, O direito constitucional e a efetividade de suas normas - limites e possibilidade da Constituição brasileira, Rio de Janeiro: Renovar, 2006, p. 264.

63 Jorge Munhoz e Carolina Barros Fidalgo, Legislação Administrativa para Concurso, Salvador: JusPodivm, 2015, p. 42.

64 Hely Lopes Meirelles, Direito administrativo brasileiro, São Paulo: Malheiros, 2007, p. 440.

65 Raymundo Faoro, Os donos do poder: formação do patronato político brasileiro, São Paulo: Globo, 2012 , p. 819.

66 Claudia Costin, Administração Pública, Rio de Janeiro: Elsevier, 2010, passim.

67 Sérgio de Buarque Holanda, Raízes do Brasil, São Paulo: Companhia das Letras, 2014 passim. 
Para o funcionário "patrimonial", a própria gestão política apresenta-se como assunto de seu interesse particular; as funções, os empregos e os benefícios que deles se aufere relacionam-se a direitos pessoais do funcionário e não a interesses objetivos, como sucede no verdadeiro Estado burocrático, em que prevalecem a especialização das funções e o esforço para se assegurarem garantias jurídicas aos cidadãos. A escolha dos homens que irão exercer funções públicas faz-se de acordo com a confiança pessoal que mereçam os candidatos e muito menos de acordo com suas capacidades próprias. Falta a tudo ordenação impessoal que caracteriza a vida no Estado burocrático ${ }^{68}$.

Segundo Weber ${ }^{69}$, a Administração será caracterizada pela desordem e ausência de objetividade, se prevalecer o patrimonialismo, uma vez que a gestão da res publica será tratada como se fosse coisa privada do gestor público. Assim, o patrimonialismo atende às demandas particulares do gestor público, por "considerações pessoais", e tem seu processo caracterizado pela subjetividade, e não pelas regras objetivas da Administração, afinal "o cargo e o exercício do poder público estão a serviço da pessoa do senhor, por um lado, e do funcionário agraciado com o cargo, por outro, e não de tarefas 'objetivas ${ }^{\prime \prime \prime 70}$.

O Poder Executivo Federal, de maneira tímida, editou o Decreto 5.497/2005, no art. $1 .^{\circ}, \S 4 .^{\circ}$, em que prevê que a nomeação de servidores comissionados somente é efetivada para o Grupo-Direção e Assessoramento Superiores níveis 1 a 4, quando o percentual mínimo de número de servidores em carreira ocupante do grupo supra, considerando o órgão e a entidade em questão, for cumprido.

Todavia, ante essa forma patriarcal no trato com a coisa pública, o Supremo decidiu pela condenação de um Deputado Federal que usou de influência e pressão política junto ao Presidente da República para manter o diretor de uma sociedade de economia mista federal, tendo afastado a tese defensiva de que o parlamentar estava exercendo atividade político-partidária, advinda da dinâmica existente no presidencialismo de coalizão ${ }^{71}$.

Isso porque o condenado, em contraprestação, recebia quantias advindas dos contratos ilegais mantidos pela empresa com empreiteiras privadas. Consignou a Corte, que o Deputado deixou de cumprir suas funções de fiscalização, prevista no artigo 49, inciso X da Constituição Federal, sendo que o modus operandi somente se tornou possível em razão da nomeação sem critérios do diretor,

68 Ibid., p. 175.

69 MAX WEBER, Economia e sociedade: fundamentos da sociologia compreensiva, v. 2. Brasília: Editora UnB, 2015, passim. Cf.: MAX WEBER, Economia e sociedade: fundamentos da sociologia compreensiva, vol. 1. Brasília: Editora da Universidade de Brasília, 2015, passim.

70 Ibid., p. 255.

71 STF, Ação Penal: 996/DF. DJ: 29/05/2018. Disponível em: http://portal.stf.jus.br/processos/ detalhe asp? incidente $=5083040$, acesso em 03 de dez. de 2019 . 
característica que os requisitos elencados pelo artigo 17 da Lei 13.303/2016 buscam amenizar, impondo critérios para a nomeação.

Este é somente mais um exemplo, dentre outros julgados pelos Tribunais Superiores $^{72}$, que enquadram o uso indevido de servidores como improbidade administrativa (artigo 9. ${ }^{\circ}$, inciso IV) ou como crime previsto no Decreto-Lei 201/1967 (artigo $1 .^{\circ}$, inciso II), em virtude da facilidade do desvio de finalidade das funções dos comissionados, utilizando-se da pressão existente em razão da demissão ad nutum.

Como bem ressalta Bresser Pereira ${ }^{73}$, isto não é visto mais como valor, sendo a criação do Departamento Administrativo do Serviço Público (DASP) em 1938, um dos percussores para o profissionalismo da burocracia brasileira, da mesma forma a positivação do concurso público desde a Constituição brasileira de 1934 (artigo 170, 2. ${ }^{\circ}$ ).

A burocracia, no sentido aqui utilizado, não se trata de sistema estruturalmente ineficiente, moroso na solução de questões e indiferentes às necessidades pessoais, mas sim na existência de um sistema de execução da atividade pública, com especialização das funções dos servidores, com cargos definidos, atuando com base em um regulamento fixo, com hierarquia e responsabilidades marcadas.

Para Weber ${ }^{74}$, a racionalização do trabalho ocorre de modo eficiente quando pautado pela autoridade racional-legal, que se mantém em conformidade com regras criadas de modo racional, com limites de poder determinados com base na esfera de competência. Assim, a autoridade racional-legal, que envolve um corpo administrativo organizado, forma-se em estrutura burocrática ${ }^{75}$.

A compreensão burocrática da Administração, impessoal e equitativa no acesso aos cargos públicos, está prevista nos tratados e convenções dos quais o Brasil é signatário. Exemplo disto é a Convenção Americana de Direitos Humanos que no artigo 23, 1, C, prevê igualdade de acesso aos cargos públicos, assim como a Declaração Universal de Direitos Humanos de 1948, que dispõe sobre o acesso de forma igualitária às funções públicas do país (artigo 21.2.2) e o Pacto Internacional sobre Direitos Civis e Políticos, art. 25 c) de igual teor.

Com a Emenda Constitucional n. ${ }^{\circ} 45 / 2004$, que acrescentou o $\S 3 .^{\circ}$ ao artigo 5. ${ }^{\circ}$ da Constituição Federal, permitiu-se que os tratados de direitos humanos, aprovados pelo Congresso Nacional com votação em dois turnos e aprovação por três quintos dos votos dos respectivos membros, passassem a ter caráter de emenda constitucional.

72 STJ, Recurso Especial: 877.106/MG. DJ: 18/08/2009. Ver também: STJ, Recurso Especial: 1.244.377/PR. DJ: 03/04/2014.

73 Luiz Carlos Bresser Pereira, op. cit., passim.

74 MAX WEBER, op. cit., passim.

75 Vitor Frederico Kümpel, Noções Gerais de Direito e Formação Humanística, São Paulo: Saraiva, 2012, p. 323. 
Consoante o entendimento jurisprudencial do Supremo, os tratados de direitos humanos não aprovados na forma prevista no dispositivo supracitado possuem status de supralegalidade, com força paralisante da lei infraconstitucional, como se deu com a prisão civil do depositário infiel, prevista como ilegal no Pacto de São José da Costa Rica, originando a Súmula Vinculante n. ${ }^{\circ} 25^{[76]}$.

Portanto, o referido Pacto, aprovado antes da EC n. ${ }^{\circ} 45 / 04$ e depois da $\mathrm{CF} / 88$, está hierarquicamente abaixo das normas constitucionais, mas acima das normas ordinárias do ordenamento ${ }^{77}$, o que exige do país a obrigatoriedade de sua observância, inclusive como forma de cumprimento das obrigações assumidas internacionalmente, consoante se depreende da leitura da norma constitucional do artigo $5 .^{\circ}, \S 2 .^{\circ}$.

Ademais, apesar de os tratados não aprovados na forma do $\S 3 .^{\circ}$ do artigo 5. ${ }^{\circ}$ da Carta Magna não fazerem parte do bloco de normas constitucionais, que podem ser utilizadas para o controle de constitucionalidade via difusa ou concentrada, a doutrina defende o seu uso para o controle de convencionalidade pela via difusa ${ }^{78}$. Isso porque os tratados não aprovados na forma de emenda possuem caráter de normas materialmente constitucionais, mas não formalmente. Isso permite que todos os juízes e tribunais locais, a requerimento das partes ou de ofício, possam invalidar as leis internas que afrontem os tratados internacionais de direitos humanos dos quais o país é signatário.

Interpretar a Convenção Americana de Direitos Humanos em conjunto ao subprincípio da necessidade impede que uma norma minore outro direito de forma demasiada e descabida, como ocorre com o concurso público quando se criam milhares de cargos comissionados de maneira desproporcional, tornando possível a invocação do controle de convencionalidade, consoante já exposto. Outrossim, o art. $5 .^{\circ}$, LXXVIII, $\S 2 .^{\circ}$, da CFRB é de clareza solar ao proteger direitos e garantias também decorrentes de tratados internacionais, como é a Convenção supra.

Salutar a aplicação do entendimento não apenas aos aprovados dentro do número de vagas, mas também quando verificada a elevada desproporção entre comissionados e efetivos, em nítido favorecimento aos servidores precários. Nesse diapasão, possível a nomeação daqueles que, embora não estejam dentro do número de vagas, sejam abrangidos pela vacância nos respectivos cargos na lei que institui a carreira pública.

Vale acrescentar que essa compreensão permite dar máxima realização ao art. 37, II da Constituição Federal e ao Pacto de São José inter alia. Assim, dando

76 STF, Súmula Vinculante 25. DJ: 23/12/2009. Disponível em: http://www.stf.jus.br/portal/ jurisprudencia/menuSumario.asp?sumula 1268 \&termo=, acesso em 20 de jun. de 2019.

77 Bruna Pinotti Garcia e Rafael De Lazari, Manual de Direitos Humanos, Salvador: JusPodivm, 2015, p. 76.

78 Valério De Oliveira Mazzuoli, Curso de Direito Internacional Público, Rio de Janeiro: Forense, 2018 , p. 332. 
efetividade ao artigo supra, combatendo o apadrinhamento em excesso. Como bem destaca o Min. Celso de Melo na ADI $1458^{[79]}$ :

Se o Estado deixar de adotar as medidas necessárias à realização concreta dos preceitos da Constituição, em ordem a torná-los efetivos, operantes e exequíveis, abstendo-se, em consequência, de cumprir o dever de prestação que a Constituição lhe impôs, incidirá em violação negativa do texto constitucional.

Em pesquisa da jurisprudência sobre o tema, encontrou-se um decisum datado de 2013 do Supremo Tribunal de Justiça (STJ), de relatoria do Min. Napoleão Maia. Naquela oportunidade, a Primeira Turma do Tribunal da Cidadania assentou a possibilidade de concessão de pedido em mandado de segurança quando houver desproporcionalidade na criação de cargos comissionados.

Tribunal local consignou que ficou demonstrado nos autos o elevado número de servidores comissionados e/ou temporários na Administração Pública, em detrimento aos servidores concursados, razão pela qual entendeu pelo cabimento da concessão da segurança pleiteada ${ }^{80}$.

No mesmo sentido, a decisão do STF em sede de agravo regimental na suspensão de segurança, em que a Suprema Corte reafirmou a primazia na nomeação dos aprovados em concurso em relação aos servidores comissionados.

Prevalência da nomeação de aprovados em concurso em detrimento da livre nomeação de pessoas desprovidas de vínculo com a Administração para o exercício do mesmo cargo. Agravo regimental não provido. 1. Os aprovados em concurso público devem ter preferência na nomeação para o exercício da função para a qual estão habilitados, máxime quando em confronto com pessoas livremente contratadas e sem vínculo efetivo com a Administração Pública ${ }^{81}$.

Entretanto, tal entendimento constitucional ainda não foi enfrentando pelo Supremo Tribunal Federal em Repercussão Geral, mas seria razoável reinterpretar o ato de nomeação de aprovados em concurso público em prol daquele entendimento que mais efetive a Constituição Federal.

79 STF, Ação Direta de Inconstitucionalidade: 1458/DF (Medida Liminar). DJ: 23/05/1996. Disponível em: http://redir.stf.jus.br/paginadorpub/paginador.jsp?docTP=AC\&docID= 347068, acesso em 27 de dez. de 2019.

80 STJ, Agravo Regimental no Recurso Especial: 1.188.144/GO. DJ: 08/11/2013.

81 STF, Agravo Regimental na Suspensão de Segurança: 5075/PI. DJ: 22/02/2019. Disponível em: http://portal.stf.jus.br/processos/downloadPeca.asp?id=153397 29691\&ext=.pdf, acesso em 20 de dez. de 2019. 


\section{DA FORÇA VINCULANTE DOS PRECEDENTES JUDICIAIS}

A doutrina preconiza a existência de uma aproximação entre os sistemas jurídicos do common law e do civil law, aquele advindo de países que desenvolveram o direito a partir das decisões dos tribunais (como nos Estados Unidos da América e no Reino Unido), e não mediante atos executivos e legislativos, como ocorre com o sistema do civil law, baseado no direito romano (como na França, na Alemanha, na Espanha, em Portugal e, consequentemente, no Brasil $)^{82}$.

Ocorre que há doutrinadores brasileiros como Theodoro Júnior ${ }^{83}$ que lecionam a existência de uma aproximação entre o sistema romano (civil law), adotado pelo ordenamento brasileiro, e o common law. Tal modo de aplicação das normas, com obrigatoriedade de observância dos precedentes de caráter vinculante, tornou-se clara com os dispositivos que tratam dos recursos no Código de Processo Civil, aprovado em 16/03/2015 (Lei n. ${ }^{\circ} 13.105 / 2015$ ).

A previsão segue os intentos abalizados pelo legislador constituinte reformador que, com a Emenda Constitucional n. ${ }^{\circ}$ 45/2004, conhecida como Reforma do Judiciário, incluiu a Repercussão Geral e as súmulas com força vinculante (artigos 102, §3. ${ }^{\circ}$, e 103-A), regulamentada esta pela Lei n. ${ }^{\circ} 11.417 / 2006$.

Determina o caput do artigo 926 do Código Processual que os Tribunais devem manter sua jurisprudência uniforme, estável e coerente, criando um ambiente decisório isonômico e previsível, conferindo segurança jurídica aos jurisdicionados, além de previsibilidade, estabilidade, desestímulo à litigância excessiva, confiança, igualdade perante a jurisdição, coerência, respeito à hierarquia e economia processual ${ }^{84}$, consoante preconiza o $\S 4 .^{\circ}$ do artigo 927 do CPC.

Em observância ao dever de coerência, os Tribunais não podem ignorar seus próprios precedentes (Enunciado 454 do Fórum Permanente de Processualistas Civis - FPPC), nos termos do inciso $\mathrm{V}$ do artigo 927 do CPC, e devem decidir em conformidade com o ordenamento jurídico (Enunciado 456 do FPPC).

Por esta razão, o STF deliberou pela existência de Repercussão Geral no Recurso Extraordinário n. ${ }^{\circ}$ 1.041.210/SP (Tese 1010) ${ }^{85}$. Para tanto, destacou-se a relevância jurídica, econômica e social da controvérsia (artigo 1.035, § $1 .{ }^{\circ}$

82 Wallace Ricardo Magri, "Introdução ao Estudo do Direito", in: Álvaro de Azevedo Gonzaga e Nathaly Campitelli Roque (coords.), Vade mecum bumanístico, Rio de Janeiro: Forense; São Paulo: Método, 2014, p. 20.

83 Humberto Theodoro Júnior, "Common Law e Civil Law. Aproximação. Papel da Jurisprudência e Precedentes Vinculantes no Novo Código de Processo Civil. Demandas Repetitivas". Disponível em: http://genjuridico.com.br/2019/02/06/common-law-e-civillaw-aproximacao-papel-da-jurisprudencia-e-precedentes-vinculantes-no-novo-codigo-deprocesso-civil-demandas-repetitivas/, acesso em 06 de dez. de 2019.

84 Daniel Amorim Assumpção Neves, Manual de Direito Processual Civil, Salvador: JusPodivm, 2018, p. 1392.

85 STF, op. cit., loc. cit. 
do CPC) por envolver a aplicação de diversos princípios constitucionais, além de transcender os limites subjetivos da demanda, considerando que o debate foi suscitado em sede de controle de constitucionalidade na origem, podendo a decisão servir de base para casos semelhantes.

Tendo como base a jurisprudência da Corte, necessário analisar o cabimento ou não da reclamação constitucional, prevista no artigo 102, inciso I, alínea "1" da Constituição Federal e que, segundo o STF, possui natureza jurídica de ação, para questionar atos da Administração Pública ou decisões judiciais que não observem a Tese 1010 .

Determina o inciso II do artigo 988 do CPC que caberá reclamação pela parte interessada ou pelo Ministério Público para garantir a autoridade das decisões do Tribunal. No entanto, antes da entrada em vigor do Novo Código de Ritos e visando a redução do número de reclamações diretas na Corte ${ }^{86}$, a Lei 13.256/2016 alterou o $\S 5 .^{\circ}$ do dispositivo supracitado para determinar o não cabimento da reclamação para garantia de decisão firmada em acórdão de Recurso Extraordinário (RE) com Repercussão Geral reconhecida se ainda não esgotadas as instâncias ordinárias.

Sendo assim, segundo Daniel Amorim Assumpção $\mathrm{Neves}^{87}$, as decisões proferidas pelo Supremo em sede de RE com Repercussão Geral possuem eficácia média, já que o uso da reclamação somente é cabível após o esgotamento das demais instâncias. Diferente se dá nos casos de julgamentos proferidos em controle concentrado de constitucionalidade, súmulas vinculantes, incidente de resolução de demandas repetitivas e incidente de assunção de competência (artigo 988, caput do CPC), que permitem o uso da ação direta no Supremo, possuindo, segundo o autor, eficácia vinculante grande.

Ademais, analisando a jurisprudência do Pretório Excelso, verifica-se que este possui o entendimento no sentido de que, se uma decisão em sede de Recurso Extraordinário reafirmar o entendimento já proferido em uma ação de controle de constitucionalidade (ADI, ADC ou ADPF), a reafirmação substitui a decisão de caráter objetiva. Neste caso, será necessário o esgotamento das instâncias ordinárias para que o interessado possa fazer uso da reclamação constitucional $^{88}$. Por outro lado, se uma decisão em Recurso Extraordinário alterar o entendimento anterior da Corte firmado em controle concentrado,

86 Fredie Didier Júnior e Leonardo Carneiro da Cunha, Curso de Direito Processual Civil: o processo civil nos tribunais, recursos, ações de competência ordinária de tribunal e querela nullitatis, incidentes de competência originária de tribunal, vol. 3, Salvador: JusPodivm, 2016, p. 540.

87 Daniel Amorim AssumpÇão NeVES, op. cit., p. 1404.

88 STF, Reclamação: 27.789/BA. DJ: 23/11/2017. Disponível em: http://portal.stf.jus.br/ processos $/$ detalhe asp? incidente $=523162>$, acesso em 05 de dez. de 2019. Ver também: STF, Reclamação: 28.623/BA. DJ: 12/12/2017. Disponível em: http://portal.stf.jus.br/ processos/detalhe.asp?incidente $=5282111$, acesso em 05 de dez. de 2019 . 
continua sendo cabível a reclamação, pois este recurso passa a ter os mesmos atributos da ação objetiva anteriormente proferida ${ }^{89}$.

Ante o exposto, portanto, conclui-se pela impossibilidade de uso da reclamação direta no Supremo em caso de violação da Tese 1010 por atos administrativos ou decisões judiciais impugnáveis por recursos, somente sendo possível o questionamento direto na Corte Superior após o esgotamento das instâncias ordinárias.

\section{CONSIDERAÇÕES FINAIS}

Em face ao exposto, conclui-se que embora haja discricionariedade da Administração Pública no ato de nomeação de candidatos aprovados em concurso público e servidores comissionados, este encontra alguns limites na própria Constituição Federal: implica haver cumprimento do art. 37, II.

É exemplar disso, as decisões elencadas ao longo da exposição proferidas pelos Tribunais Superiores com relação ao direito subjetivo dos candidatos a serem nomeados. Os entendimentos supracitados possuem caráter vinculante e/ou persuasivo em razão da nova sistemática adotada pelo Código de Processo Civil, que exige a observância da jurisprudência dos Tribunais Superiores pelos Tribunais de piso, mantendo a unidade, coerência, integridade e segurança jurídica (Art. 927, III do CPC).

Ademais, o entendimento no sentido de que o ato de nomeação é vinculado, neste ponto, é imperioso: constatado o número elevado de servidores comissionados, e, portanto, desproporcional ao número de efetivos, traduz de modo salutar a regra preconizada pelo Constituinte brasileiro ao determinar que o ingresso nos cargos públicos deve ocorrer por meio do concurso público.

Nesse sentido, não haveria discricionariedade da Administração Pública, constituindo um dever atenuar o número de servidores comissionados em prol dos efetivos, conforme exposto na Carta Magna e detalhado no entendimento do próprio STF, o qual determinou o mínimo de $50 \%$ de efetivos.

Não obstante, outra interpretação poderia ferir a Convenção Americana de Direito Humanos inter alia, visto que a norma que institui as dezenas de cargos comissionados minora a acessibilidade aos demais cidadãos, privilegiando o apadrinhamento político - o patrimonialismo.

Desse modo, a nomeação de servidores precários impõe observância ao princípio da razoabilidade e proporcionalidade, que limitam a discricionariedade administrativa, a fim de que os atos não extravasem os limites da conveniência e oportunidade gerando a violação à interpretação autêntica do artigo 37, II, da Tese 1010 e do RE 598099/MS, entre outros.

89 STF, Reclamação: 18.636/PB. DJ: 16/11/2015. Disponível em: http://portal.stf.jus.br/ processos/detalhe.asp?incidente $=4634905$, acesso em 05 de dez. de 2019 . 


\section{BIBLIOGRAFÍA}

Alkimin, Maria Aparecida e Lincoln Zub Dutra. "O ativismo judicial como instrumento de transformação do Estado Democrático de Direito". Revista Direito \& Paz, v. 1, n. ${ }^{\circ} 34,2016$, pp. 300-318.

Alexy, Robert. Teoria dos Direitos Fundamentais. São Paulo: Malheiros, 2008.

Ávila, Humberto. Teoria dos Princípios: da definição à aplicação dos princípios jurídicos. São Paulo: Malheiros, 2004.

BARroso, Luís Roberto. O direito constitucional e a efetividade de suas normas - limites e possibilidade da Constituição brasileira. Rio de Janeiro: Renovar, 2006.

Barroso, Luís Roberto. O controle de constitucionalidade no direito brasileiro. São Paulo: Saraiva Educação, 2019.

Barroso, Luís Roberto. Direito Constitucional Contemporâneo. São Paulo: Saraiva Educação, 2020.

Bresser Pereira, Luiz Carlos. "Gestão do setor público: estratégia e estrutura para um novo Estado". In: Luiz Carlos Bresser Pereira e Peter Spink (orgs.), Reforma do Estado e Administração Pública gerencial. Rio de Janeiro: Editora FGV, 2006.

Bresser Pereira, Luiz Carlos. Reforma do Estado para a cidadania: a reforma gerencial brasileira na perspectiva internacional. Brasília: ENAP, 1998.

Canotilho, José Joaquim Gomes. Constituição dirigente e vinculação do legislador: contributo para a compreensão das normas constitucionais programáticas. Coimbra: Editora Coimbra, 2001

Costin, Claudia. Administração Pública. Rio de Janeiro: Elsevier, 2010.

Cunha Junior, Dirley Da. Curso de Direito Constitucional. Salvador: Juspodivm, 2012.

Didier Júnior, Fredie e Leonardo Carneiro da Cunha. Curso de Direito Processual Civil: o processo civil nos tribunais, recursos, ações de competência ordinária de tribunal e querela nullitatis, incidentes de competência originária de tribunal, vol. 3. Salvador: JusPodivm, 2016.

FAoro, Raymundo. Os donos do poder: formação do patronato político brasileiro. São Paulo: Globo, 2012.

Frischeisen, Luiza Cristina Fonseca. Políticas Públicas - A Responsabilidade do Administrador e o Ministério Público. São Paulo: Max Limonad, 2000.

Garcia, Bruna Pinotti e Rafael de Lazari. Manual de Direitos Humanos. Salvador: JusPodivm, 2015. 
Garcia, Emerson e Rogério Pacheco. Improbidade Administrativa. Rio de Janeiro: Lúmen Júris, 2013.

García de Enterría, Eduardo. La Constitución como norma y el tribunal constitucional. Madrid: Civitas, 2001.

Gonzaga, Álvaro de Azevedo e Roberto Beijato Junior. "Hermenêutica Jurídica". In: Álvaro de Azevedo Gonzaga e Nathaly Campitelli Roque (coords.), Vade mecum bumanístico. Rio de Janeiro: Forense - São Paulo: Método, 2014.

Guastini, Riccardo. "A Constitucionalização do ordenamento jurídico e a experiência italiana". In: Claudio Pereira de Souza Neto e Daniel Sarmento (coords.), A Constitucionalização do Direito: fundamentos teóricos e aplicações específicas. Rio de Janeiro: Lumen Juris, 2007.

Hesse, Konrad. A Força Normativa da Constituição. Porto Alegre: Safe, 2004.

Holanda, Sérgio De Buarque. Raízes do Brasil. São Paulo: Companhia das Letras, 2014

Kümpel, Vitor Frederico. Noções Gerais de Direito e Formação Humanística. São Paulo: Saraiva, 2012.

Lassale, Ferdinand. O que é uma Constituição. Belo Horizonte: Líder, 2002.

Loewenstein, Karl. Teoría de la constitución. Barcelona: Ariel, 1976.

Magri, Wallace Ricardo. "Introdução ao Estudo do Direito". In: Álvaro de Azevedo Gonzaga e Nathaly Campitelli Roque (coords.), Vade mecum bumanístico. Rio de Janeiro: Forense; São Paulo: Método, 2014.

Mazzuoli, Valério De Oliveira. Curso de Direito Internacional Público. Rio de Janeiro: Forense, 2018.

Meirelles, Hely Lopes. Direito administrativo brasileiro. São Paulo: Malheiros, 2007.

Mello, Celso Antônio Bandeira De. Curso de Direito Administrativo. São Paulo: Malheiros, 2008.

Mendes, Gilmar Ferreira e Paulo Gustavo Gonet Branco. Curso de direito constitucional. São Paulo: Saraiva, 2012.

Müller, Friedrich. Métodos de Trabalho do Direito Constitucional. São Paulo: Max Limonad, 2000 .

Munhoz, Jorge e Carolina Barros Fidalgo. Legislação Administrativa para Concurso. Salvador: JusPodivm, 2015. 
Neto, Cláudio Pereira de Souza e Daniel Sarmento. Direito Constitucional - Teoria, bistória e métodos de trabalho. Belo Horizonte: Fórum, 2016.

Neves, Daniel Amorim Assumpção. Manual de Direito Processual Civil. Salvador: JusPodivm, 2018.

Nicz, Alvacir Alfredo. "A Jurisdição Constitucional e seu alcance: Cortes Constitucionais e Supremo Tribunal Federa"1. In: Jorge Miranda (coord.), Justiça Constitucional. São Paulo: Almedina Brasil, 2018.

Noveli, Flávio Bauer. "A eficácia dos atos administrativos". Revista de Direito Administrativo, v. 60, 1960, pp. 1-27.

Novelino, Marcelo. Curso de Direito Constitucional. Salvador: JusPodivm, 2017.

Oliveira, Rafael Carvalho Rezende. Curso de Direito Administrativo. Rio de Janeiro: Forense - São Paulo: Método, 2018.

Pedra, Anderson Sant'Ana. "A constitucionalização do direito e o controle do mérito do ato administrativo pelo judiciário". In Walber de Moura Agra, Celso Luiz Braga de Castro e André Ramos Tavares (orgs.), Constitucionalismo: os desafios do terceiro milênio. Belo Horizonte: Fórum, 2008.

StreCK, Lenio Luiz. "Bem jurídico e Constituição: da proibição de excesso (Übermaßverbot) à proibição de proteção deficiente (Untermaßverbot) ou de como não há blindagem contra normas penais inconstitucionais". Boletim da Faculdade de Direito: Universidade de Coimbra, v. 80, 2004, pp. 303-345.

Theodoro Júnior, Humberto. "Common Law e Civil Law. Aproximação. Papel da Jurisprudência e Precedentes Vinculantes no Novo Código de Processo Civil. Demandas Repetitivas". Disponível em: http:/genjuridico.co m.br/2019/02/06/ common-law-e-civil-law-aproximacao-papel-da-jurisprudencia-e-precedentes-vinculantes-no-novo-codigo-de-processo-civil-demandas-repetitivas/, acesso em 06 de dez. de 2019.

WEBER, MAX. Economia e sociedade: fundamentos da sociologia compreensiva, v. 2. Brasília: Editora da Universidade de Brasília, 2015.

\section{JURISPRUDÊNCIA}

STF. Ação Direta de Inconstitucionalidade: 1458/DF (Medida Liminar). DJ: 23/05/1996. Disponível em: http://redir.stf.jus.br/paginadorpub/paginador.jsp?docTP=AC\&docID=347068, acesso em 27 de dez. de 2019.

STF. Agravo Regimental no Recurso Extraordinário: 200.844-3/PR. DJ: 25/06/2002. Disponível em: http://redir.stf.jus.br/paginadorpub/paginador. jsp? docTP=AC\&docID=330565, acesso em 27 de dez. de 2019. 
STF. Ação Direta de Inconstitucionalidade: 2667/DF (Medida Liminar). DJ: 12/03/2004 Disponível em: http://www.stf.jus.br/portal/peticaoInicial/verPeticaoInicial.asp ?base $=$ ADIN\&s1 $=2667 \&$ processo $=2667$, acesso em 27 de dez. de 2019.

STF. Recurso Extraordinário: 365368/SC. DJ: 22/05/2007. Disponível em: http://portal. stf.jus.br/processos/detalhe.asp?incidente=2076706, acesso em 20 de dez. de 2019 .

STF. Súmula Vinculante 25. DJ: 23/12/2009. Disponível em: http://www.stf.jus.br/ portal/jurisprudencia/menuSumario.asp?sumula $=1268 \&$ termo $=$, acesso em 20 de dez. de 2019.

STF. Ação Direta de Inconstitucionalidade: 4125/TO. DJ: 15/02/2011. Disponível em: http://portal.stf.jus.br/processos/detalhe.asp?incidente $=2635406$, acesso em 20 de dez. de 2019.

STF. Recurso Extraordinário: 598.099/MS. DJ: 03/10/2011. Disponível em: http://portal. stf.jus.br/processos/detalhe.asp?incidente=2667158, acesso em 20 de dez. de 2019 .

STF. Reclamação: 18.636/PB. Disponível em: http://portal.stf.jus.br/processos/detalhe. asp?incidente $=4634905$, acesso em 05 de dez. de 2019 .

STF. Recurso Extraordinário: 837.311/PI. DJ: 09/12/2015. Disponível em: http://portal. stf.jus.br/processos/detalhe.asp?incidente $=4634356$, acesso em 20 de dez. de 2019 .

STF. Questão de Ordem na Repercussão Geral no Recurso Extraordinário: 966.177/ RS. DJ: 07/06/2017. Disponível: http://redir.stf.jus.br/paginadorpub/paginador. jsp?docTP=TP\&docID=749049106, acesso em 01 de dez. de 2019.

STF. Reclamação: 27.789/BA. DJ: 23/11/2017. Disponível em: http://portal.stf.jus.br/ processos/detalhe.asp?incidente $=5231624$, acesso em 05 de dez. de 2019 .

STF. Reclamação: 28.623/BA. DJ: 12/12/2017. Disponível em: http://portal.stf.jus.br/ processos/detalhe. asp?incidente $=5282111$, acesso em 05 de dez. de 2019 .

STF. Habeas Corpus: 152.856/DF. DJ: 15/03/2018. Disponível em: https://www.conjur. com.br/dl/hc-lewa-rj.pdf, acesso em 20 de dez. de 2019.

STF. Ação Penal: 996/DF. DJ: 29/05/2018. Disponível em: http://portal.stf.jus.br/processos/detalhe.asp?incidente $=5083040$, acesso em 03 de dez. de 2019 .

STF. Agravo Regimental na Suspensão de Segurança: 5075/PI. DJ: 22/02/2019. Disponível em: http://portal.stf.jus.br/processos/downloadPeca.asp?id=15339729691\&ext=. pdf, acesso em 20 de dez. de 2019.

STF. Recurso Extraordinário: 1.041.210/SP. DJ: 22/05/2019. Disponível em: http://portal. stf.jus.br/processos/detalhe. asp?incidente=5171382, acesso em 20 de dez. de 2019 . 
STF. Tese 1010. DJ: 22/05/2019. Disponível em: http://www.stf.jus.br/portal/jurisprudenciaRepercussao/verAndamentoProcesso. asp? incidente $=5171382 \&$ numeroProcesso $=1041210 \&$ classeProcesso $=R E \&$ numeroTema $=1010 \#$, acesso em 20 de dez. de 2019.

STF. Embargos de Declaração em Mandado de Segurança: 29.323/DF. DJ: 28/05/2019. Disponível em: http://portal.stf.jus.br/processos/downloadPeca.asp? $\mathrm{id}=15340331383 \&$ ext $=$.pdf, acesso de 01 de dez. de 2019 .

STJ. Recurso Ordinário em Mandado de Segurança: 14.220/TO. DJ: 04/02/2003

STJ. Recurso Especial: 877.106/MG. DJ: 18/08/2009.

STJ. Agravo Regimental nos Embargos de Declaração no Recurso em Mandado de Segurança: 30.054/SP. DJ: 09/10/2012.

STJ. Agravo Regimental no Recurso em Mandado de Segurança: 39748/RO. DJ: 04/04/2013.

STJ. Agravo Regimental no Recurso Especial: 1.384.295/MS. DJ: 17/10/2013.

STJ. Embargos de Declaração no Recurso em Mandado de Segurança: 30.776/RO. DJ: 17/09/2013.

STJ. Agravo Regimental no Recurso Especial: 1.188.144/GO. DJ: 08/11/2013.

STJ. Agravo Regimental no Recurso Especial: 1.402.265/PE. DJ: 04/02/2014.

STJ. Agravo Regimental no Agravo em Recurso Especial: 453.742/RO. DJ: 20/03/2014.

STJ. Recurso Especial: 1.244.377/PR. DJ: 03/04/2014.

STJ. Agravo Interno no Recurso Especial: 1.444.111/RN. DJ: 01/03/2018. 